\title{
Evaluasi Ergonomi dan Perancangan Fasilitas pada Institut Teknologi Bandung
}

\author{
Herman R. Soetisna ${ }^{1}$, Wida Rahmasari ${ }^{2}$, Putra A.R. Yamin ${ }^{3}$ \\ ${ }^{1,2)}$ Fakultas Teknologi Industri, Program Studi Teknik Industri, ITB \\ Jl. Ganesa 10 Bandung 40132 \\ Email: hermanrs@ti.itb.ac.id,wida.rahmasari@s.itb.ac.id,putrayamin@itb.ac.id
}

\begin{abstract}
ABSTRAK
Institut Teknologi Bandung merupakan salah satu isntitusi pendidikan tinggi di Indonesia yang bertujuan untuk menjadi universitas kelas dunia, dengan menetapkan tiga pilar strategis: peran institusi, infrastruktur, dan pengembangan institusi. Evaluasi ergonomi dilakukan di Institut Teknologi Bandung untuk mengidentifikasi sarana dan prasarana pendukung pendidikan yang sudah baik dilihat dari sudut pandang ergonomi dan memberikan rekomendasi pada sarana dan prasarana yang belum memperhatikan aspek ergonomi dalam perancangannya. Penelitian ini dibantu dengan diskusi bersama UPT K3L ITB dan Direktorat Sarana dan Prasarana ITB. Dalam penelitian ini, ditemukan 60 kasus dengan 57 jenis permasalahan yang dikelompokkan menjadi tiga prioritas, yaitu prioritas satu, dua dan tiga. Pengelompokan ini menggunakan Risk Assessment Matrix yang didasarkan pada frekuensi kejadian dan dampak yang ditimbulkan. Masing-masing rekomendasi perbaikan dilengkapi dengan estimasi biaya menggunakan analisis SNI sebagai salah satu aspek pertimbangan dalam pengelompokkan permasalahan. Setelah dikelompokkan, 43 permasalahan masuk ke dalam prioritas satu, 10 permasalahan masuk ke dalam prioritas dua, dan 4 permasalahan masuk ke dalam prioritas tiga. Total estimasi biaya untuk untuk mengimplementasi rekomendasi penyelesaian permasalahan prioritas satu adalah sebesar Rp 3.423.346.841 hingga Rp 4.312.211.240, prioritas dua sebesar Rp 6.350.001 hingga Rp 16.501.000, dan prioritas tiga sebesar Rp 11.005.800 dengan mempertimbangkan alternatif rekomendasi yang dipilih pada setiap masalah.
\end{abstract}

Kata kunci: Ergonomi, ITB, Rekomendasi, Asesmen, Sarana dan Prasarana

\begin{abstract}
As one of higher education institution in Indonesia, Institut Teknologi Bandung has the goal to be world-class university with three strategic foundations: institution's vision and mission, internal \& external network, and institution building. One of the focus on the institution building is provides physical infrastructure as the support of educational activities. Ergonomic assessment was done in Institut Teknologi Bandung with the purpose to identify the infrastructure as good-design in the perspective of ergonomics and to recommend better designs to the bad-ergonomic-design infrastructure according to ergonomic principles. According to the observation done in Institut Teknologi Bandung and the interview with the management of Institut Teknologi Bandung, there are 60 cases found in term of bad ergonomic design which are classified to the 13 categories. Problems found at the observation were analyzed and re-design according the literature study of ergonomic design. The problems are classified into three priorities: 1, 2, and 3. The classifying process was done by scoring each of the problem by its impact to the users and frequency of occurrence in the Risk Matrix Assessment. For the problems with less than $R p 100.000$ worth of cost recommendations, they are automatically put into the priority 1 . In the total 60 cases found, there are 57 different problems grouped according to its priorities. 43 problems classified as priority 1, 10 problems classified as priority 2, and 4 problems classified as priority 3. Cost estimates to implement the re-design recommendations of priority 1 is $R p$ 3.495.007.541 to Rp 4.406.164.940, priority 2 is $R p$ 7.240.000 to Rp 17.371.000, and priority 3 is $R p$ 19.582.600.
\end{abstract}

Keywords: ergonomic, ITB, recommendations, assessment, infrastructure

\section{Pendahuluan}

Mengacu pada RENIP ITB 2006-2025 [9], arah pengembangan jangka panjang ITB telah menetapkan tiga pilar strategis yang menjadi perhatian: peran institusi (institution's vision and mission), infrastruktur (internal \& external network), dan pengembangan institusi (institution building). Selanjutnya menurut Direktorat Pengembangan ITB, dalam Penataan Lingkungan Fisik, pengembangan diarahkan pada perwujudan kampus sebagai lingkungan yang kondusif dalam mendukung proses pembelajaran dan mewujudkan lingkungan kampus yang sehat, bersih dan nyaman dengan mewujudkan ITB sebagai green campus.

Ergonomi merupakan suatu cabang ilmu yang sistematis untuk memanfaatkan informasi-informasi mengenai sifat, kemampuan, dan keterbatasan manusia dalam merancang suatu sistem kerja sehingga orang dapat hidup dan bekerja pada sistem itu dengan baik, yaitu mencapai tujuan yang diinginkan melalui pekerjaan tersebut dengan efektif, aman, sehat, nyaman, dan efisien (Sutalaksana, [14]). Untuk mewujudkan sistem kerja yang ideal tersebut, terdapat metode perbaikan dengan meninjau pada aspek ergonomi dengan menyesuaikan sistem kerja dengan pengguna (Heglin [5], Kroemer [7], Pheasant \& Haslegrave [8], Kodak [16]). Tinjauan ergonomi meliputi tinjauan displai visual (Wijnholds [17]), antropometri (Nidiaputri 
\& Ardiyanto [10]), lingkungan fisik (Arminas, [2]), dan biomekanika kerja (Ariyani [1]). Prinsip Human Centered Design (HCD) digunakan untuk meninjau sistem kerja yang dirancang dengan kriteria yang disesuaikan dengan penggunanya. Menurut Sutalaksana [14] dan Nurmianto [11], faktor-faktor penting yang perlu diperhatikan dalam menerapkan prinsip HCD, antara lain interaksi antara manusia dan bahan, interaksi antara manusia dan mesin (fasilitas), serta interaksi antara manusia dengan lingkungan.

Perancangan sistem melalui pendekatan ergonomi sangat penting untuk menghindari kecelakaan yang ditimbulkan, seperti menurut (Pulat [13]) bahwa akan diperoleh beragai kerugian jika prinsip-prinsip ergonomi tidak diterapkan dalam perancangan. Kerugian-kerugian tersebut antara lain adalah meningkatkan frekuensi ketidakhadiran (absenteeism), meningkatkan biaya pengobatan, menurunkan kualitas pekerjaan, menimbulkan cedera, serta meningkatkan probabilitas terjadinya kecelakaan. Hal ini sejalan dengan temuan pada penelitian Prabaswari dkk [13].

Asesmen ergonomi dilakukan dengan tujuan untuk mengidentifikasi sistem kerja yang dikategorikan baik dan belum baik dengan tinjauan ergonomi. Bila diperlukan, dilakukan perbaikan sistem kerja melalui rekomendasi perbaikan yang dibuat dengan tujuan untuk meningkatkan quality of working life bagi pengguna.

\section{Metode Penelitian}

\section{Subjek Penelitian}

Studi permasalahan dengan observasi dilakukan pada fasilitas-fasilitas perlalulintasan di Kota Bandung meliputi fasilitas pendukung kegiatan belajar dan penelitian seperti gedung dan fasilitas, jalur pejalan kaki, dan jalur teduh, sistem keamanan seperti hydrant, dan alat pemadam api ringan (APAR), sistem wayfinding seperti display nama gedung dan fasilitas, rambu lalu lintas dan marka jalan, fasilitas pendukung lainnya seperti tempat pembuangan sampah, lahan parkir di dalam kampus dan lahan parkir di sekitar kampus, fasilitas peningkatan aksesibilitas pada gedung seperti emergency exit dan bagi diffable seperti jalur kursi roda.

Wawancara dilakukan pada UPT K3L ITB dan Direktorat Sarana dan Prasarana ITB untuk mendapatkan informasi mengenai keadaan infrastruktur yang ada di dalam wilayah kampus ITB. Pada sarana dan prasarana yang tersedia, dilakukan pengukuran dimensi dan inventarisasi ketersediaannya untuk meminimalkan potensi permasalahan sejenis.

\section{Desain Eksperimen}

Metode yang digunakan dalam penelitian ini, yaitu wawancara, observasi, pengukuran, estimasi biaya dan penentuan skala prioritas (Sekaran [12]). Wawancara digunakan untuk membantu menentukan prioritas permasalahan, menemukan isu-isu yang diangkat, dan mendapatkan data-data yang dibutuhkan terkait keadaan sarana dan prasarana di Institut Teknologi Bandung. Observasi dilakukan menggunakan kamera, kursi roda dan alat-alat bantu lainnya. Pengukuran terhadap sarana dan prasarana meliputi pengukuran dimensi menggunakan meteran. Estimasi biaya dilakukan menggunakan analisis biaya dengan Standar Nasional Indonesia. Penentuan skala prioritas permasalahan dilakukan dengan menggunakan risk assessment matrix dan pertimbangan besaran estimasi biaya.

Observasi dilakukan dengan mengamati fasilitas-fasilitas perlalulintasan di Kota Bandung. Seluruh sistem perlalulintasan berjalan seperti biasa saat observasi dilakukan. Observasi diikuti dengan pengambilan gambar menggunakan kamera dan pengujian terhadap sarana dan prasarana, seperti pada jalur kursi roda (ramp) menggunakan kursi roda. Pada masing-masing sarana dan prasarana juga dilakukan pengukuran dan inventarisasi secara menyeluruh.

Estimasi biaya rekomendasi dilakukan untuk setiap permasalahan yang diangkat dengan menggunakan analisis biaya dengan Standar Nasional Indonesia. Analisis biaya yang dilakukan meliputi biaya konstruksi, biaya pembelian alat dan bahan, serta biaya jasa pertukangan.

Setiap permasalahan kemudian dianalisis menggunakan risk assessment matrix berdasarkan skala dampak dan frekuensi kejadian. Selanjutnya dikelompokkan ke dalam tiga jenis prioritas, yaitu prioritas satu, dua atau tiga. Prioritas digunakan untuk membantu pihak manajemen dalam memutuskan prioritas perancangan perbaikan desain.

\section{Hasil dan Pembahasan}

\section{Daftar Permasalahan}

Dari total 60 kasus yang ditemukan, terdapat 57 jenis permasalahan terkait dengan gedung dan fasilitas, jalur pejalan kaki, dan jalur teduh, sistem keamanan seperti hydrant, dan alat pemadam api ringan (APAR), sistem wayfinding seperti display nama gedung dan fasilitas, rambu lalu lintas dan marka jalan, fasilitas pendukung lainnya seperti tempat pembuangan sampah, lahan parkir di dalam kampus dan lahan parkir di sekitar kampus, fasilitas peningkatan aksesibilitas pada gedung seperti emergency 
exit dan bagi diffable seperti jalur kursi roda. Pada Gambar 1 ditampilkan 13 kategori masalah yang dikemukakan dan seluruh permasalahan disajikan dalam Tabel 1.
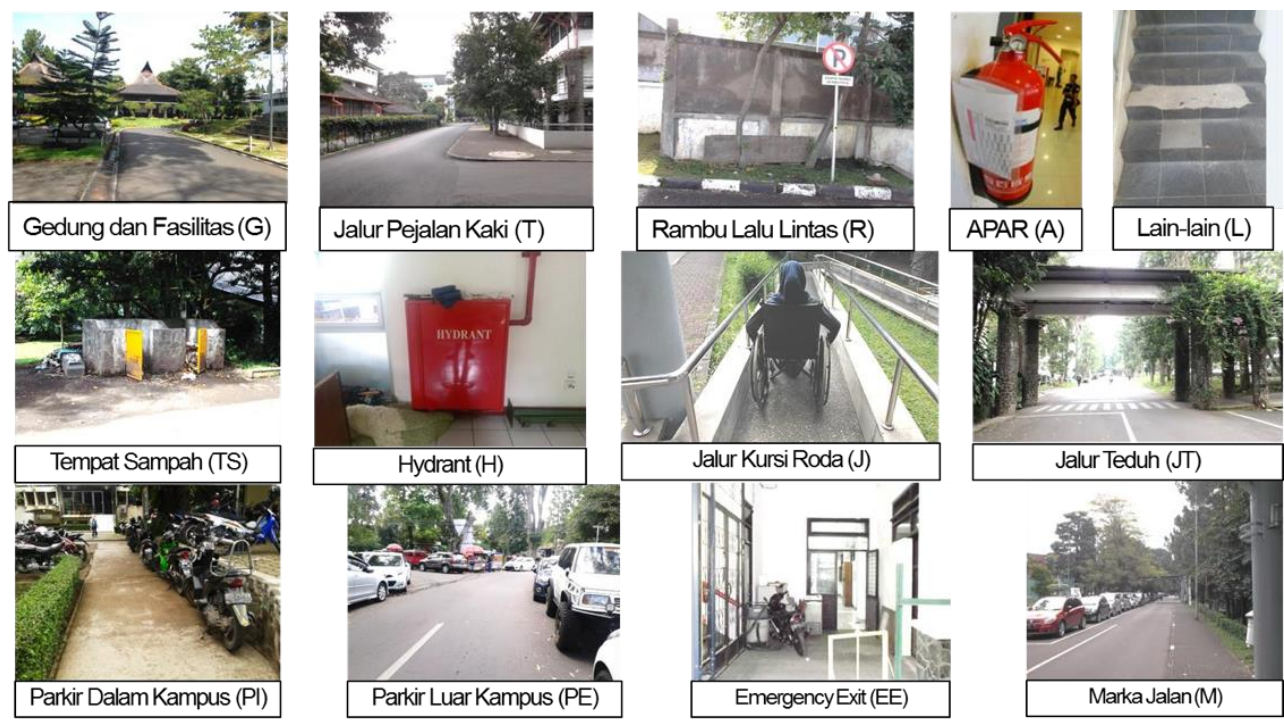

Gambar 1. Kategori Permasalahan Ergonomi pada Institut Teknologi Bandung

Tabel 1 Daftar Permasalahan pada Fasilitas Perlalulintasan di Kota Bandung

\begin{tabular}{|c|c|c|}
\hline No & Kode & Permasalahan \\
\hline 1 & A-01 & Terdapat Meja di Bawah APAR \\
\hline 2 & $\mathrm{~A}-02$ & Tidak ada Tanda Pemasangan APAR \\
\hline 3 & $\mathrm{~A}-03$ & APAR Tidak Dilengkapi Lembar Pemeriksaan \\
\hline 4 & G-01 & Petunjuk Toilet Sulit Dilihat dari Jarak Jauh \\
\hline 5 & G-02 & Tidak Ada Petunjuk Toilet di Koridor \\
\hline 6 & G-03 & Petunjuk Nama Gedung Terhalang Pohon \\
\hline 7 & G-04 & Display Penuh Sticker \\
\hline 8 & G-05 & Nama Jalan yang Tidak Kontras dan Terhalang Pohon \\
\hline 9 & G-06 & Petunjuk Arah Toilet (Missing) \\
\hline 10 & G-07 & Display Nama Gedung Terhalang Kanopi \\
\hline 11 & G-08 & Display Nama Gedung Memantulkan Cahaya \\
\hline 12 & G-09 & Tulisan Nama Gedung Tidak Jelas \\
\hline 13 & G-10 & Label Penunjuk Ruangan Berukuran Terlalu Kecil \\
\hline 14 & G-11 & Stop Kontak Tanpa Keterangan \\
\hline 15 & G-12 & Musholla Tanpa Petunjuk Nama \\
\hline 16 & G-13 & Gedung Aula Barat Tanpa Display Nama \\
\hline 17 & G-14 & Display Petunjuk Ruangan Berukuran Kecil dan Terlalu Tinggi \\
\hline 18 & EE-01 & Pintu Emergency Exit Terhalang Benda \\
\hline 19 & EE-02 & Hanya Terdapat Satu Pintu Keluar \\
\hline 20 & $\mathrm{H}-01$ & Hydrant Terhalang Parit \\
\hline 21 & $\mathrm{H}-02$ & Hydrant Terhalang Tanaman \\
\hline 22 & $\mathrm{H}-03$ & Benda Berada di Jalur Akses Hydrant \\
\hline 23 & $\mathrm{H}-04$ & Hydrant Terhalang Kendaraan Parkir \\
\hline 24 & $\mathrm{H}-05$ & Selokan di Depan Hydrant \\
\hline 25 & $\mathrm{H}-06$ & Hydrant Tertutup Sticker \\
\hline 26 & $\mathrm{H}-07$ & Hydrant Tanpa Status Pengecekan \\
\hline 27 & $\mathrm{H}-08$ & Hydrant Terhalang Pembatas Tangga \\
\hline 28 & $\mathrm{~J}-01$ & Lebar Jalur Kursi Roda Tidak Memadai \\
\hline 29 & $\mathrm{~J}-02$ & Ramp Diskontinu \\
\hline 30 & $\mathrm{~J}-04$ & Benda-benda Disimpan di Jalur Ramp \\
\hline 31 & $\mathrm{~J}-05$ & Saluran Air di Jalur Ramp \\
\hline 32 & $\mathrm{~J}-06$ & Ramp 12 Terlalu Curam \\
\hline 33 & $\mathrm{~J}-07$ & Lebar Ramp Tidak Memadai \\
\hline
\end{tabular}




\begin{tabular}{lll}
\hline No & Kode & \multicolumn{1}{c}{ Permasalahan } \\
\hline 34 & J-08 & Tidak Ada Ramp Menuju Gedung \\
\hline 35 & J-09 & Jalur Ramp Terhalang Pagar \\
\hline 36 & JT-01 & Jalur Teduh Tidak Menghubungkan Seluruh Gedung \\
\hline 37 & JT-02 & Tidak Ada Jalur Teduh antara Gedung Kimia dan GKU Timur \\
\hline 38 & L-01 & Keramik Tangga CC Barat Rusak \\
\hline 39 & M-01 & Jalur Penyebrangan Tanpa Zebra Cross \\
\hline 40 & M-02 & Warna Zebra Cross Pudar \\
\hline 41 & M-03 & Marka Garis Tengah \\
\hline 42 & PE-02 & Mobil Parkir di Badan Jalan \\
\hline 43 & PI-02 & Motor Parkir di Badan Jalan \\
\hline 44 & PI-03 & Parkir Kendaraan Tidak Seragam \\
\hline 45 & PI-04 & Marka Parkir Motor pada Jalur Pejalan Kaki \\
\hline 46 & PI-05 & Pembatas Parkir Berbahaya \\
\hline 47 & R-01 & Rambu STOP Terhalang Tanaman \\
\hline 48 & R-02 & Letak Rambu Larangan Parkir yang Membingungkan \\
\hline 49 & R-03 & Letak Rambu Terhalang Mobil Parkir \\
\hline 50 & R-04 & Rambu STOP Tidak Dipatuhi Pengendara Bermotor \\
\hline 51 & R-05 & Letak Rambu di Kanan Jalan \\
\hline 52 & R-06 & Rambu Larangan Parkir Sejajar Jalan \\
\hline 53 & T-01 & Tidak Ada Trotoar di Tepi Jalan F ITB \\
\hline 54 & T-02 & Tidak Ada Petunjuk Himbauan Berjalan di Trotoar \\
\hline 55 & T-03 & Tidak Ada Trotoar di Ruas Jalan ITB \\
\hline 56 & T-04 & Display Himbauan Berjalan di Trotoar di Badan Jalan \\
\hline 57 & TS-01 & Display Tempat Sampah yang Kurang Tepat \\
\hline 58 & TS-02 & Sampah Berserakan di Sekitar Tempat Sampah \\
\hline
\end{tabular}

\section{Rekomendasi Perbaikan}

Dalam penelitian ini, seluruh masalah yang telah diidentifikasi akan dilengkapi dengan rekomendasi-rekomendasi perbaikan yang dapat diterapkan. Rekomendasi perbaikan yang diberikan disajikan dalam bentuk rancangan yang langsung diimplementasikan sesuai dengan prinsip ergonomi, untuk menghasilkan sistem kerja yang Efektif, Aman, Sehat, Nyaman dan Efisien (EASNE). Sebagai salah satu contoh, pada permasalahan ketiadaan trotoar di ruas jalan di dalam kampus (T-03). Trotoar merupakan salah satu fasilitas yang menjamin keamanan dan keselamatan pejalan kaki saat berada di ruas jalan. Mengacu pada Peraturan Menteri Pekerjaan Umum No. 30/PRT/M/2006 [6], terdapat empat elemen aksesibilitas yang harus dipenuhi di setiap lokasi, yaitu, kemudahan, kegunaan, keselamatan, dan kemandirian. Pejalan kaki juga memiliki hak yang sama untuk dapat mengakses suatu tempat dengan mudah, menggunakan fasilitas yang baik, aman, dan mengakses secara mandiri. Di ITB, trotoar hanya tersedia di ruas jalan 4, jalan G, dan sebagian jalan J. Ketiadaan trotoar menyebabkan terjadinya pejalan kaki berjalan di ruas jalan dengan risiko kecelakaan lalu lintas, seperti pada Gambar 2.
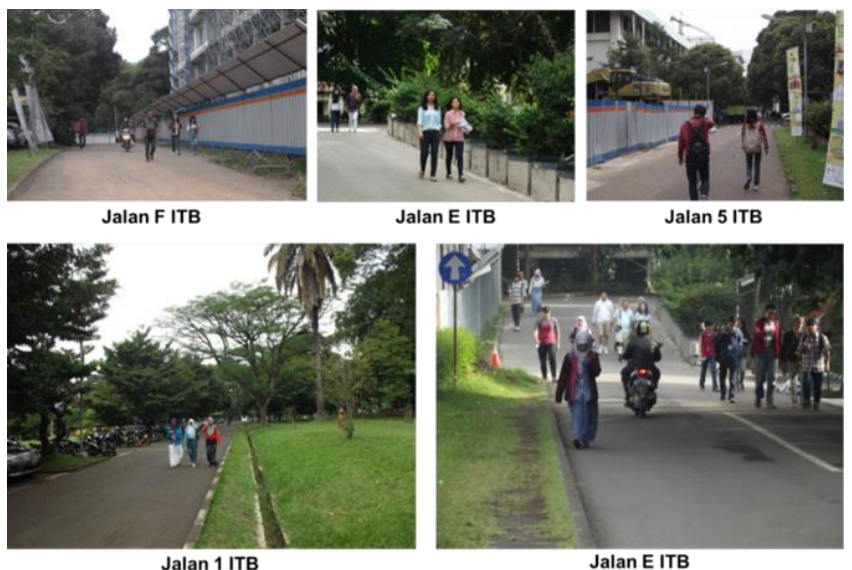

Gambar 2. Fenomena Pejalan Kaki Berjalan di Badan Jalan

Untuk meningkatkan aksesibilitas pejalan kaki dan menciptakan sistem kerja yang EASNE, maka dirancang trotoar di seluruh ruas jalan ITB dengan memanfaatkan ruang yang tersedia, sepanjang $3 \mathrm{~km}$ dengan lebar trotoar sesuai standar yaitu 1,2 meter. 
Gambar 3 merupakan ilustrasi usulan trotoar di ruas jalan ITB (warna hijau) dan ketersediaan trotoar yang telah ada (berwarna kuning).

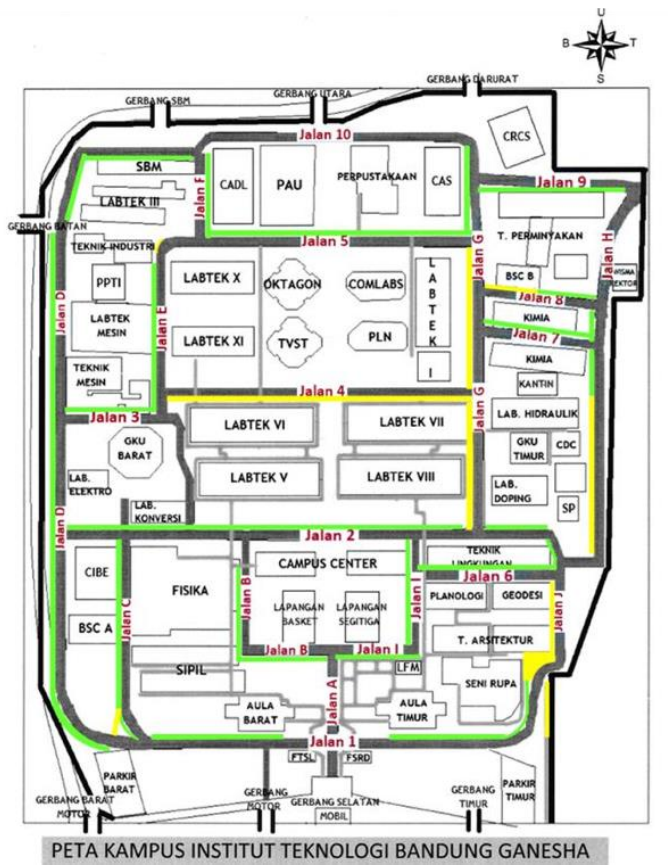

Gambar 3. Peta Perancangan Trotoar di Seluruh Ruas Jalan (Usulan)

Trotoar dirancang berdasarkan peraturan yang berlaku (Direktur Jenderal Perhubungan Darat [3] dan Federal Aviation Administration [4]) dan mempertimbangkan aspek ergonomis. Untuk meminimalkan penggunaan badan jalan yang dialihfungsikan sebagai trotoar, maka trotoar dirancang pada lahan yang telah disediakan, seperti di atas taman dan selokan. Gambar 4 menunjukkan ilustrasi perancangan trotoar dengan memanfaatkan lahan yang tersedia.
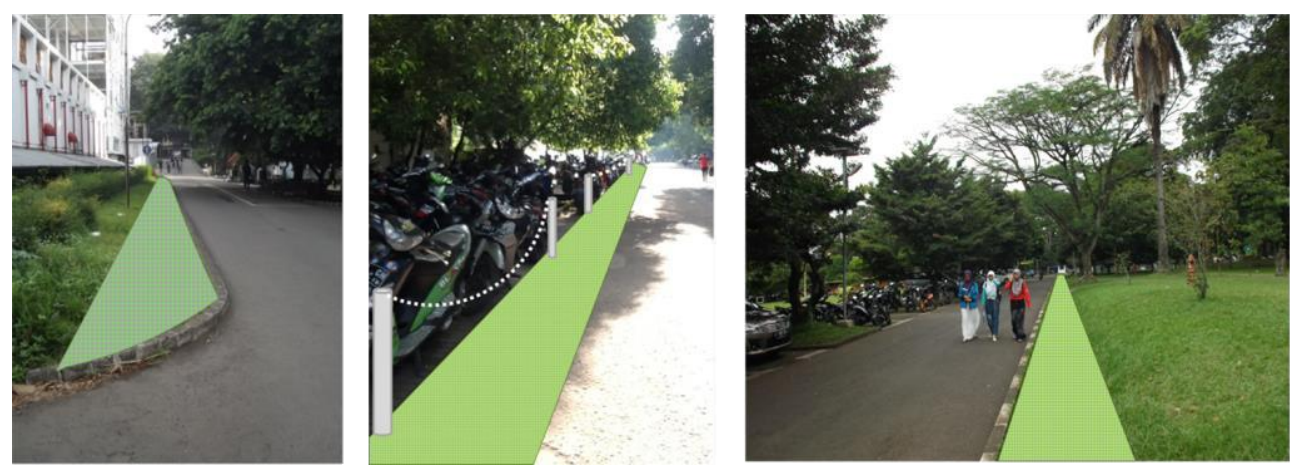

Gambar 4. Ilustrasi Rancangan Trotoar diatas Taman dan Selokan (Usulan)

Tabel 1. Judul tabel ditulis dengan huruf besar di awal saja demikian juga dengan judul-judul dalam tabel

\begin{tabular}{|c|c|c|c|}
\hline Kebutuhan & Jumlah & Harga satuan & Total Biaya \\
\hline Grill besi & $2816 \mathrm{~kg}$ & Rp 20.000 per kg & Rp 56.320.000 \\
\hline Cat besi hitam & $106 \mathrm{~kg}$ & Rp 80.000 per kg & $\operatorname{Rp} 8.480 .000$ \\
\hline Pekerja & 14 orang hari & Rp 80.000 per orang per hari & Rp 1.120 .000 \\
\hline Tukang Besi & 14 orang hari & Rp 100.000 per orang per hari & Rp 1.400 .000 \\
\hline Kepala Tukang Besi & 7 orang hari & Rp 120.000 per orang per hari & Rp 840.000 \\
\hline Mandor & 7 orang hari & Rp 150.000 per orang per hari & Rp 1.050 .000 \\
\hline
\end{tabular}




\section{Prioritas Permasalahan}

Selanjutnya, 58 jenis permasalahan tersebut dikelompokkan menjadi 3 kelompok prioritas, yaitu prioritas 1, prioritas 2, dan prioritas 3. Pengelompokkan permasalahan ke dalam prioritas masalah dilakukan dengan mempertimbangkan analisis risiko dan pertimbangan besar-kecilnya estimasi biaya yang dibutuhkan dalam perbaikan.

Tabel 3 merupakan matriks prioritas permasalahan yang ditentukan berdasarkan frekuensi kejadian dan dampak yang dihasilkan. Melalui pengelompokkan ini didapatkan prioritas 1 sebanyak 44 permasalahan, prioritas 2 sebanyak 10 permasalahan, dan prioritas 3 sebanyak 4 permasalahan.

Tabel 3 Matriks Prioritas Permasalahan Fasilitas Perlalulintasan di Kota Bandung

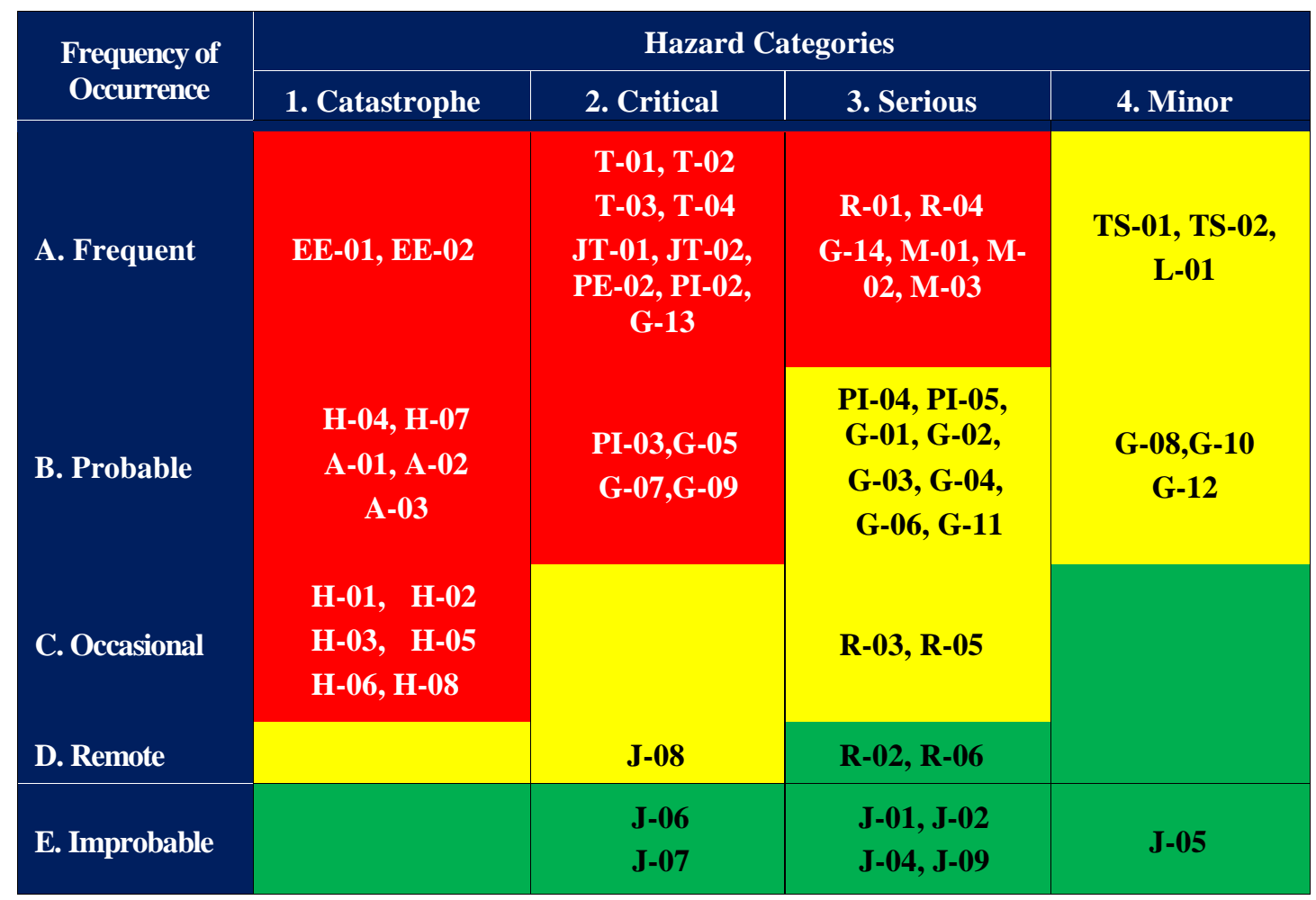

Setelah dilakukan pengelompokkan berdasarkan frekuensi kejadian dan dampak, permasalahan yang masuk dalam sel yang berwarna merah akan menjadi prioritas 1, sel kuning merupakan prioritas 2, dan sel hijau merupakan prioritas 3. Selanjutnya, permasalahan yang terdapat pada prioritas 2 dan prioritas 3 akan dipindahkan menjadi prioritas 1 apabila memiliki biaya rekomendasi yang relatif rendah (di bawah Rp100.000). Permasalahan yang dikelompokkan dalam prioritas 1, memiliki kepentingan yang tinggi untuk diselesaikan dan menjadi usulan bagi pemangku kepentingan dalam melakukan proses perbaikan sistem.

\section{Pembahasan}

Melalui penelitian ini, ditemukan bahwa permasalahan yang terjadi tidak hanya pada fasilitas fisik saja. Untuk mengantisipasi hal ini, maka perlu diterapkan suatu sistem yang dapat menjamin efektivitas implementasi perbaikan, yaitu sistem 7E-1M. Sistem 7E-1M merupakan sistem yang terdiri atas Engineering, Educating the People, Enforcing the Law, Empowering the People, Enabling the System, Engaging the Top Leader to the System, Endorsing the Partners dan Maintaining the System (and Continuing the Improvement).

Engineering yang dilakukan berupa perancangan Sistem keselamatan dan kesehatan kerja sebagai upaya penanggulangan kebakaran dirancang dan dikelompokkan menjadi tiga kategori, yaitu pengendalian setiap bentuk energi, penyediaan sarana deteksi, alarm, pemadam kebakaran dan sarana evakuasi, serta pembentukan unit penanggulangan kebakaran di tempat kerja.

Educating the People merupakan sosialisasi atau edukasi terhadap hal-hal yang baru dirancang, termasuk sanksi-sanksi yang diterapkan bagi pihak yang melanggar. Sosialisasi dapat diberikan kepada pegawai dan mahasiswa dengan memperkenalkan 
apa itu api dan unsur yang dapat membuat api menyala. Sosialisasi juga dapat dilakukan dalam bentuk pengenalan perangkat pemadam kebakaran dan pelatihan kepada setiap civitas ITB untuk meningkatkan awareness terhadap lingkungan kerja yang aman.

Enforcing the Law merupakan tindakan yang dilakukan untuk memaksa masyarakat melaksanakan peraturan/perbaikan yang baru diterapkan. Salah satu cara yang dapat dilakukan untuk membiasakan sistem baru yang dirancang adalah pemberian punishment atau hukuman apabila tidak menerapkan sistem. Kepada petugas yang tidak melaksanakan tugasnya, diberikan hukuman berupa potongan penghasilan atau pemberian surat peringatan tergantung kesalahan yang dilakukan.

Empowering the People merupakan sistem sumbang saran yang dapat menampung kritik dan saran masyarakat. Cara yang dapat diberlakukan adalah membangun "Sistem Sumbang Saran" (Suggestion System) untuk menampung usulan, kritik, atau saran dari masyarakat, termasuk laporan bila menemukan sarana pemadam kebakaran yang tidak sesuai dengan standar yang berlaku, contohnya bila menemukan APAR yang telah kadaluarsa dan belum dilakukan penggantian. Pada sistem ini, terdapat pihak yang bertugas menindaklanjuti laporan-laporan tersebut dengan melakukan pemeriksaan, analisis dan pengembangan solusi.

Enabling the System merupakan tindakan yang dilakukan agar perbaikan yang diterapkan dapat dijalankan. Pada contoh sistem pemadam kebakaran di ITB, mobil pemadam kebakaran harus dapat difungsikan sebagai mana mestinya. Salah satu sarana pemadam kebakaran yang disediakan adalah pompa mesin diesel yang berada di masing-masing gedung untuk menyuplai hydrant di gedung tersebut.

Engaging the Top Leader to the System diartikan sebagai keterlibatan pimpinan (puncak) dalam kegiatan-kegiatan (dan rapatrapat) yang dilakukan oleh para panitia kerja yang sedang membangun sistem yang diperlukan untuk suatu program yang direncanakan. Untuk meningkatkan keterlibatan seluruh pihak di dalam kampus pada sistem pemadaman kebakaran yang dirancang, dilakukan engagement berupa safety drill atau safety induction yang diikuti pula oleh level manajemen untuk menunjukkan bahwa aspek ini merupakan aspek yang sangat penting.

Endorsing the Partners diartikan sebagai upaya peningkatan keterlibatan pihak-pihak eksternal yang melakukan pekerjaan di dalam lingkup sistem. Pihak eksternal juga diberi arahan untuk mengikuti peraturan yang diberlakukan di dalam kampus ITB.

Maintaining the System (and Continuing the Improvement) diartikan sebagai tindakan untuk menjaga agar sistem dapat terlaksana dengan baik. Salah satu caranya adalah dengan melakukan evaluasi kinerja sarana dan prasarana yang berada di lingkungan kampus ITB dan melakukan perbaikan secara terus menerus untuk menghasilkan sistem yang lebih baik.

\section{Kesimpulan dan Saran}

Hasil asesmen ergonomi yang dilakukan pada gedung dan fasilitas pada Institut Teknologi Bandung yang meliputi aksesibilitas, keamanan, wayfinding, dan kenyamanan dapat diambil kesimpulan Terdapat total 60 kasus yang ditemukan pada asesmen ergonomi di Institut Teknologi Bandung, dengan 58 permasalahan; 44 permasalahan termasuk prioritas satu, 10 permasalahan termasuk prioritas dua, dan 4 permasalahan termasuk prioritas tiga. Berikutnya, estimasi biaya untuk mengimplementasi rekomendasi penyelesaian permasalahan prioritas satu adalah sebesar minimal Rp 3.495.007.541 hingga maksimal Rp 4.406.164.940, prioritas dua sebesar minimal Rp 7.240.000 hingga maksimal Rp 17.371.000, dan prioritas tiga sebesar Rp 19.582.600.

\section{Daftar Pustaka}

[1] Ariyani, E. (2017). Hubungan Penanganan Beban Manual dengan Nyeri Punggung Bawah Pada Karyawan PT. Perdagangan dan Perindustrian Bangkinang, Ergonomi dan K3, 2(2), pp. 12-19.

[2] Arminas (2016). Perancangan Fasilitas Kerja dan Perbaikan Postur Kerja pada Aktivitas Manual Material Handling Karyawan Toko Mega Mas Elektronik Makassar, Ergonomi dan K3, 1(1), pp. 34-42.

[3] Direktur Jenderal Perhubungan Darat. (2014). Petunjuk Teknis Perlengkapan Jalan. Jakarta: Departemen Perhubungan.

[4] Federal Aviation Administration. (Tanpa tahun). Character and Symbol Size. Dipetik Juni 2015, dari FAA Human Factors Awareness Web Course: http://www.hf.faa.gov/Webtraining/VisualDisplays/text/size1a.htm

[5] Heglin, H. J. (1974). Applied Ergonomics. Navship Display Illumination Design Guide 2113: Human Factors, 5, 241. 
[6] Kementerian Pekerjaan Umum. (2006). Peraturan Menteri Pekerjaan Umum No. 30/PRT/2006: Pedoman Teknis Fasilitas dan Aksesibilitas Pada Bangunan Gedung dan Lingkungan. Indonesia: Departemen Pekerjaan Umum.

[7] Kroemer, K. K. (2001). Ergonomics: How to Design for Ease and Efficiency Second Edition. New Jersey: Prentice Hall, Inc.

[8] Pheasant, S., \& Haslegrave, C. M. (2005). Bodyspace: Anthropometry, Ergonomics and the Design of Work, Third Edition. Florida: CRC Press.

[9] Majelis Wali Amanat Institut Teknologi Bandung. (2007). Surat Keputusan Majelis Wali Amanat Institut Teknologi Bandung No. 015/SK/K01-MWA/2007. Bandung.

[10] Nidiaputri, A. \& Ardiyanto, A. (2017). Hand Anthropometry of Indonesian Young Adult Females. Ergonomi dan K3, 2(1), pp. 19-26.

[11] Nurmianto, E. (1991). Ergonomi Konsep Dasar dan Aplikasinya. Surabaya: Prima Printing

[12] Sekaran, U. (2006). Metode Penelitian Bisnis. Jakarta, Indonesia: Salemba Empat.

[13] Pulat, B. M. (1991). Industrial Ergonomics: Case Studies. ISA: Institute of Industrial Engineers.

[14] Prabaswari, A.D., Maulda, M., Sari, A.D., (2017). Analisis Resiko Keselamatan dan Kesehatan Kerja pada Pekerja Bagian Pengemasan Minipack Menggunakan Metode Job Safety Analysis (JSA) pada Perusahaan XYZ. Ergonomi dan K3, 2(1), pp. 27-34.

[15] Sutalaksana, I. Z., Anggawisastra, R., \& Tjakraatmaja, J. (2006). Teknik Perancangan Sistem Kerja. Bandung: Penerbit ITB.

[16] The Eastman Kodak Company. (2003). Kodak's Ergonomic Design for People at Work. New York: John Wiley \& Sons, Inc.

[17] Wijnholds, A. D. (1997). Using Type: The Typoghrapher's Craftmanship and the Ergonomist's Research. 